\title{
Heavy metals present in Ficus benjamina leaves in the metropolitan area of Guadalajara, Mexico
}

\section{Metales pesados presentes en hojas de Ficus Benjamina en el área metropolitana de Guadalajara, México}

PEÑA-GARCÍA, Laura $\dagger^{*}$, MACIEL-FLORES, Roberto, ROSAS-ELGUERA, José and ROBLESMURGUÍA, Celia

Universidad de Guadalajara. Centro Universitario de Ciencias Biológicas y Agropecuarias. Camino Ramón Padilla Sánchez 2100, Nextipac, 44600 Zapopan, Jal.

ID $1^{\text {st }}$ Author: Laura, Peña-García / ORC ID: 0000-0002-9008-133, Researcher ID Thomson: U-4752-2018, CVU CONACYT ID: 311129

ID $1^{\text {st }}$ Coauthor: Roberto, Maciel-Flores / ORC ID 0000-0002-3540-860X

ID $2^{\text {nd }}$ Coauthor: José, Rosas-Elguera / CVU CONACYT ID: 10786

ID $3^{\text {rd }}$ Coauthor: Celia, Robles-Murguía / ORC ID: 0000-0001-6413-0478, CVU CONACYT ID: 81038

DOI: $10.35429 /$ EJRG.2019.9.5.1.12

Received June 12, 2019; Accepted December 30, 2019

\begin{abstract}
Goals: General: The collection of dust samples deposited on Ficus benjamina leaves in the Guadalajara metropolitan area (GMA) will allow the identification of heavy metals and their spatial distribution. Specific: Identify the most polluted areas of the city and the elements present by means of particle dispersion schemes (maps) made with the data obtained by the atomic absorption technique. Metodología: For the extraction of heavy metals an acid digestion was performed. The samples were previously homogenized. The determination was made on an atomic absorption spectrophotometer model Varian AA 240 FS, with a monochromator of CZERNY-TURNER design, panel of 4 lamps and inert and adjustable nebulization chamber. The technique used was flame (flame) and calibration curves were used. Contribución: The concentrations of the seven metals analyzed $\mathrm{Cu}, \mathrm{Zn}, \mathrm{Co}$, $\mathrm{Ni}, \mathrm{Cd}, \mathrm{Pb}$ and $\mathrm{Cr}$ were identified, the most abundant being $\mathrm{Cu}$ and $\mathrm{Pb}$. The maps allowed to identify that there are some patterns of distribution of the contamination, such was the case of the $\mathrm{Cd}, \mathrm{Pb}$ and $\mathrm{Zn}$ that are distributed very homogeneously on the Lázaro Cárdenas avenue until reaching the supply market area.
\end{abstract}

Atomic absorption, Heavy metals, GMA

\begin{abstract}
Resumen
Objetivos General: La recolección de muestras de polvo depositado en hojas de Ficus benjamina en el área metropolitana de Guadalajara (AMG), permitirá identificar metales pesados y su distribución especial. Específico: Identificar las zonas más contaminadas de la ciudad y los elementos presentes mediante esquemas (mapas) de dispersión de partículas elaborados con los datos obtenidos por la técnica de absorción atómica. Metodología: Para la extracción de metales pesados se realizó una digestión ácida. Las muestras se homogenizaron previamente. La determinación se realizó en un espectrofotómetro de absorción atómica modelo Varian AA 240 FS, con un monocromador de diseño CZERNY-TURNER, panel de 4 lámparas y cámara de nebulización inerte y ajustable. La técnica empleada fue de flama (llama) y se utilizaron curvas de calibración. Contribución: Se identificaron las concentraciones de los siete metales analizados $\mathrm{Cu}, \mathrm{Zn}, \mathrm{Co}, \mathrm{Ni}, \mathrm{Cd}, \mathrm{Pb}$ y $\mathrm{Cr}$, siendo los más abundantes el $\mathrm{Cu}$ y el $\mathrm{Pb}$. Los mapas permitieron identificar que se tienen algunos patrones de distribución de la contaminación, tal fue el caso del $\mathrm{Cd}, \mathrm{Pb}$ y $\mathrm{Zn}$ que se distribuyen muy homogéneamente sobre la avenida Lázaro Cárdenas hasta llegar a la zona del Mercado de abastos.
\end{abstract}

Absorción atómica, Metales pesados, AMG

Citation: PEÑA-GARCÍA, Laura, MACIEL-FLORES, Roberto, ROSAS-ELGUERA, José and ROBLES-MURGUÍA, Celia. Heavy metals present in Ficus benjamina leaves in the metropolitan area of Guadalajara, Mexico. ECORFAN JournalRepublic of Guatemala. 2019, 5-9: 1-12

\footnotetext{
* Correspondence to Author (email: sansanchez@itesi.edu.mx)

$\dagger$ Researcher contributing first author.
} 


\section{Introduction}

One of the causes of air pollution is present with greater force in cities heavily congested by traffic and with little rainfall. This causes heavy metal accumulation that comes from the friction products of brakes, discs, wheels and the pavement itself on the communication roads. Although asbestos has been eliminated in brake ballasts, metals such as iron (Fe), manganese $(\mathrm{Mn})$, copper $(\mathrm{Cu})$, antimony $(\mathrm{Sb})$, barium $(\mathrm{Ba})$, zirconium $(\mathrm{Zr})$, in addition to zinc $(\mathrm{Zn})$ They are present in the tires (Querol, 2008).

Few studies have been carried out in the identification and estimation of the concentration of heavy metals using leaves of plants collected in the Guadalajara Metropolitan Area (AMG) (Gutiérrez, 2013, 2015). In this regard, it has been reported that the concentration of heavy metals $(\mathrm{Al}, \mathrm{Cd}, \mathrm{Cu}, \mathrm{Fe}$, $\mathrm{Mn}, \mathrm{Ni}, \mathrm{Pb}$ and $\mathrm{Zn}$ ) accumulated in Ficus benjamina sheets that was determined by atomic absorption, depended on the season of the year and the metal (Gutiérrez, 2013). For example, in the Bosque de Los Colomos in the spring season a higher concentration of lead (10.39 $\pm 1.88 \mathrm{mg}$ / Kg-1) was determined than in the summer (4.99 $\pm 1.88 \mathrm{mg} / \mathrm{Kg}-1)$ and for $\mathrm{Cu}$ the concentration It increased almost five times in the summer (Gutiérrez, 2013). When comparing the contaminant retention capacity of the Ficus benjamina leaf with other leaves (C. aurantium and Fraxinus uhdei), it was demonstrated that this Ficus species retains a higher concentration of $\mathrm{Pb}$ in spring, summer and autumn, while in the summer and winter seasons it retains higher concentrations of $\mathrm{Cu}$ than other leaves (Gutiérrez, 2013). The reported results suggest that Ficus benjamina leaves have a great capacity to accumulate metals and therefore can be used as bioindicators of environmental particles.

\section{Components and origin of pollutants}

The most common air pollutants are suspended particles whose components include heavy metals, nitrates and sulfates, among others. (Perez Fadul \& Hdrnandez Hernandez, 2006). In particular, heavy metals are a group of elements that are found in relatively low concentrations in the earth's crust, soils and plants, have industrial and biological importance and have densities greater than $6 \mathrm{~g} / \mathrm{cm} 3$ (Martinez, 2009; Virtual, 2011).
Air pollutants have the ability to generate more severe health problems if heavy metals such as lead $(\mathrm{Pb})$, zinc $(\mathrm{Zn})$, cadmium $(\mathrm{Cd})$ and chromium (Cr) are found (David et al., 1989; Flores et al., 2013; WHO, 2006; Vargas, 2005).

Hypothesis: The particles deposited in Ficus benjamina leaves from air pollution in the AMG, consist of a wide variety of heavy metals that can affect human health

Goals: Identify heavy metals and evaluate their concentration in urban dust deposited in Ficus benjamina leaves by means of atomic absorption techniques (AA).

\section{Health effects}

Air pollution by particles has been associated with various effects, acute and chronic, in respiratory and cardiovascular diseases, given the diversity in chemical composition (Frejo et al., 2011). Women suffer greater exposure to traditional environmental risks, such as the use of solid fuels in cooking and water transport (WHO, 2016). Traffic intensity is fundamental in terms of environmental pollution. People who live or work near major communication routes are particularly affected by the high levels of contamination by particles and heavy metals associated with them (Gasser et al., 2009). Agricultural, industrial and vehicular traffic companies in large cities have released a large amount of chemical pollutants into the environment, including heavy metals that are present in soils, which are transported by wind and water. These, in the long term, come into contact with the inhabitants and have the capacity to generate health and environmental problems (Juárez et al., 2009).

\section{Heavy metals}

\section{Cadmium (Cd)}

It is a metal that is available in the earth's crust along with zinc, copper and lead. Cadmium is not found in the free state in nature, but is released into water, soil and air by various anthropic activities. Almost all cadmium is obtained during the extraction and refining of non-ferrous metals, the manufacture and application of phosphate-based fertilizers, the combustion of fossil fuels and the disposal and incineration of garbage (WHO, 2006). 


\section{Applications}

In order to protect against corrosion, a cadmium bath is provided with screws, locknuts, bolts or pins and various parts of airplanes and motor vehicles (Nordberg, 1999). It is also used in batteries $(83 \%)$, pigments $(8 \%)$, electrolytic coatings $(7 \%)$, stabilizers for plastics $(1.2 \%)$, iron-free alloys, photovoltaic instruments and other uses $(0.8 \%)$.

\section{Entrance routes to the organism:}

By inhalation: through tobacco smoke or by occupational exposure to atmospheric cadmium dust, approximately $20 \%$ to $50 \%$ is absorbed via the lung. After being absorbed in the lung or digestive tract, it passes to the liver (David et al., 1989).

By supply: A small amount of cadmium (1-10\%) will enter the body through food and water intake. Although in case of not consuming enough iron or other nutritional elements in the diet, the individual is likely to absorb more cadmium than normal (ATSDR, 2012; David et al. „1989; Nordberg, 1999).

\section{Health effects:}

Cadmium is easy to find in manure (livestock) and pesticides, it can accumulate in aquatic organisms and during agricultural harvesting. Internationally, the United States Department of Health and Human Services (DHHS), the International Agency for Research on Cancer (IARC) and the Environmental Protection Agency (EPA) determined that cadmium and its compounds they are carcinogenic to humans (ATSDR, 2012a; Lenntech, 2008).

\section{Cobalt (Co)}

It is a metal that is present in the environment (in air and water) and food. It has properties similar to iron and nickel. It is present in vitamin B12. It is also useful in the treatment of anemia in pregnant women as it stimulates the production of red blood cells (ATSDR, 2001). According to the international labor organization, cobalt is considered as a sensitizing agent that can cause occupational asthma. It can also generate bronco acute spasm or pneumonia; however, in the case of chronic exposure, the damage can lead to pulmonary fibrosis (David et al., 1989).

\section{Applications:}

In high concentrations, cobalt can be found in the soil near mineral deposits, phosphated rocks or sites where minerals melt, as well as in roads with high vehicular flow, such as roads, near airports or other types of industrial pollution sources . It is also possible to find small amounts of cobalt in plants and incinerators that use coal as fuel, expelled by the exhaust pipe of vehicles and in the production and use of alloys and cobalt compounds (ATSDR, 2001; Lenntech, 2008). It has been used as a glass and ceramic dye, also for nutritional uses (beer foam stabilization) or medical (anemia treatment, even in hip and knee prostheses). It has also been used in the alloy industry with other metals, as well as in mining, in pigments and bleaches (Ilundain, 2009).

Entrance routes to the organism:

By inhalation and by drinking water

Health effects:

In the case of beer drinkers it was observed that it can generate cardiac toxicity, severe pulmonary fibrosis, asthma and pneumonitis in addition to allergies such as dermatitis and asthma (Ilundain, 2009)

\section{Chrome (Cr)}

It is an element that is found naturally in rocks, animals, plants and in the soil (ATSDR, 2012b).

\section{Applications:}

It is widely used in manufacturing processes of chromed material, as well as in numerous consumer products such as:

\section{- $\quad$ Wood treated with copper dichromate \\ - $\quad$ Tanned leather with chromic sulfate \\ - In stainless steel kitchenware \\ - $\quad$ In hip replacements}

Entrance routes to the organism:

By inhalation: in the metallurgical and tanning industry, hazardous waste sites and tobacco smoke (in closed places it can reach chromium concentrations of 10 to 400 times higher than in the open air). In rural areas, air generally contains chromium concentrations $<10 \mathrm{ng} / \mathrm{m} 3$ lower than urban air (30 ng / m3) (ATSDR, 2012b).

PEÑA-GARCÍA, Laura, MACIEL-FLORES, Roberto, ROSASELGUERA, José and ROBLES-MURGUÍA, Celia. Heavy metals present in Ficus benjamina leaves in the metropolitan area of Guadalajara, Mexico. ECORFAN Journal-Republic of Guatemala. 2019 


\section{Water and soil}

Due to its low solubility, chromium is sporadically detected in samples of groundwater, drinking water or soil, so exposure to chromium can occur due to:

\section{- Drinking water \\ - Dermal absorption when bathing \\ - $\quad$ Eat foods such as fruits, vegetables, nuts, drinks and meats.}

\section{Health effects:}

It is important to note that not all chromium is toxic to health. Chrome with valence VI is necessary for our body to survive (ATSDR, $2012 b)$ The airways in workers is the most common. The effects include irritation of the nasal mucosa, secretion and respiratory problems such as asthma, cough or shortness of breath, in addition to dermal lesions, skin ulcers. A higher incidence of lung cancer may also occur (ATSDR, 2012b; Nordberg, 1999; Ilundain et al., 2009).

\section{Copper $(\mathbf{C u})$}

It is a reddish metal that occurs naturally in rocks, water, sediments and, at low levels, in the air. The average concentration in the earth's crust is approximately $50 \mathrm{ppm}$. Copper can be released into the environment through mining and from factories that use metallic copper or copper compounds. The environment can also be released from landfills, waste incineration, domestic wastewater and fossil fuels, as well as the production of wood, phosphate-based fertilizers and natural sources such as volcanoes or forest fires (Nordberg, 1999).

\section{Applications:}

In electrical cables, wire, sheets of metal, pipes and other products. Copper compounds are commonly used in agriculture to treat plant diseases such as fungi or for water treatment and as protection for wood, leather and fabrics (ATSDR, 2016b).

Entrance routes to the organism

- $\quad$ Eyes, respiratory or ingestion.

Health effects:
In case of ingestion, it presents with blue vomit (córric salts), hepatoxocicity, hemolysis (destruction of red blood cells) or methemoblobinemia.

In case of inhalation there is fever due to metallic vapors. The fever subsides spontaneously, the patient presents chills, cough and dyspnea (respiratory distress) (Tintinalli et al., 2013). Another condition that is associated with copper is Wilson disease, a rare inherited disorder, which causes the body to not eliminate excess copper, which can be toxic (Kowdley, 2006).

\section{Nickel (Ni)}

Nickel has properties that make it desirable to form alloys. Some of the metals with which it is combined are iron, copper, chromium and zinc. Most of the nickel is used to make stainless steel. It is also combined with elements such as chlorine, sulfur and oxygen to form nickel compounds that dissolve easily in water and are used in the synthesis of coordination complexes and for industrial applications, respectively. It is found in all soils and is released during volcanic activity (ATSDR, 2016b).

\section{Applications:}

Nickel compounds are used to color ceramics, make batteries and as catalysts (to accelerate the speed of chemical reactions). Nickel is released into the atmosphere during mining, volcanic activity and by industries that manufacture or use nickel. The industry can dispose of nickel in wastewater. Nickel is also released into the atmosphere by power plants that burn oil or coal and by garbage incinerators (ATSDR, 2016b).

Entrance routes to the organism:

- $\quad$ Air, water, food intake, dermal,
sediments and soil,
- $\quad$ smoking tobacco and
- $\quad$ people with some type of prosthesis

When breathing air containing nickel, it goes to the lungs and passes into the bloodstream. The more soluble the nickel compounds in water, the more it is absorbed through the lungs. Some of these nickel particles can leave the lungs in the mucus that swallows or spits (Nordberg, 1999). 


\section{Health effects:}

Among the most serious health effects from exposure to nickel are allergies, rhinitis, sinusitis, chronic bronchitis, decreased lung function, cancers of the nasal cavity, lung and sinuses (ATSDR, 2016c).

\section{Lead $(\mathbf{P b})$}

Lead is a heavy metal that is found naturally in the earth's crust. However, it is usually combined with two or more elements (tin, copper, arsenic, antimony, bismuth, cadmium and sodium) forming lead alloys that have industrial importance (ATSDR, 2016c).

\section{Applications:}

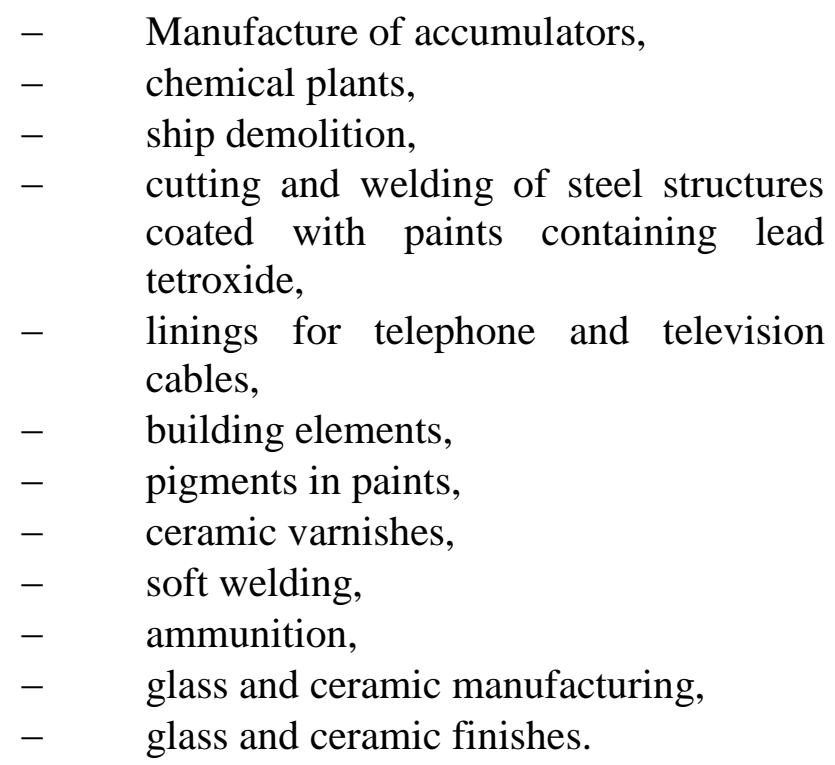

Entrance routes to the organism:

People who live near high-traffic roads or highways or power plants, fruit orchards, mining, industrial areas, incinerators, landfills and hazardous waste sites. People who are exposed to lead paints, stained glass or work in lead smelters and refineries, brass or bronze smelters, in plastics industries, in tinning, welding or trimming operations of steel and batteries manufacturing plants. Construction and demolition workers, municipal garbage incinerators, pottery and ceramic industries, radiator repair shops and other industries that use lead welding (ATSDR, 2016c). Workers' families may be exposed to lead levels when workers take work clothes home, as it contains residues of work material (Nordberg, 1999).

\section{Health effects:}

In the case of children, it has serious consequences for health because high exposure affects the brain and nervous system (WHO, 2018). Once lead enters the body by inhalation and is deposited in the lower respiratory tract, it is completely absorbed. In adults, the percentage absorbed by the gastrointestinal tract varies between 10 and $15 \%$, however, in the case of pregnant women and children, this percentage increases to $50 \%$. Once it enters the bloodstream, lead is distributed in blood, soft tissues, kidney, bone marrow, liver and brain, as well as in bones and teeth (ATSDR, 2016c).

It is important to highlight that there is no blood lead concentration level that can be considered safe (WHO, 2018).

\section{Zinc (Zn)}

Zinc is one of the most common elements in the earth's crust. The main production is from mining and the production of goods, as well as in power plants. Metallic zinc can be punched for the manufacture of auto parts, electrical equipment, light machinery tools, computer equipment, toys and ornamental items (ATSDR, 2016a; Glencore, 2019; International Zinc Association, 2017).

Applications:

$$
\begin{array}{ll}
- & \text { Galvanized steel, } \\
- & \text { Zinc based alloys } \\
- & \text { Die casting industry, } \\
- & \text { Brass and bronze production, } \\
- & \text { Minting and architectural applications. }
\end{array}
$$

\section{Health effects:}

The EPA has determined that, due to lack of information, zinc is not classifiable in terms of carcinogenesis in humans (David et al., 1989), however, if swallowed it can cause vomiting and abdominal pain (may simulate poisoning by iron). Inhalation of zinc vapors may cause mucosal irritation and fever (Tintinalli et al., 2013). 
Entrance routes to the organism:

It is found in air, soil and water and in food (ATSDR, 2016a), in military smoke bombs, zinc tablets, and in smelting or electroplating processes such as zinc oxide (Tintinalli et. Al., 2013 ). The levels of heavy metals that cause damage to health, as well as the toxic effects that harm organisms have been reported in several bibliographical sources (Dreisbach, 1984). According to Food Industry (2007) it is said that the EPA has some established limits for the intake of heavy metals in humans, which should not be exceeded, since it can cause serious disorders to living beings, including death (Table 1).

\begin{tabular}{|l|r|}
\hline \multicolumn{2}{|c|}{ Consumption by humans: } \\
Element & Maximum permissible limit \\
\hline $\mathrm{As}$ & $0.05 \mathrm{mg} / \mathrm{l}(+)$ \\
\hline $\mathrm{Cd}$ & $10 \mu \mathrm{g} / \mathrm{l}(*)$ \\
\hline $\mathrm{Cr}$ & $0.05 \mathrm{mg} / \mathrm{l}(+)$ \\
\hline $\mathrm{Cu}$ & $1.0 \mu \mathrm{g} / \mathrm{l}(\#)$ \\
\hline $\mathrm{Hg}$ & $144 \mathrm{ng} / \mathrm{l}(*)$ \\
\hline $\mathrm{Ni}$ & $632.0 \mu \mathrm{g} / \mathrm{l}(*)$ \\
\hline $\mathrm{Pb}$ & $50.0 \mu \mathrm{g} / \mathrm{l}(*)(\mathrm{adults})$ \\
\hline $\mathrm{Zn}$ & $5.0 \mu \mathrm{g} / \mathrm{l}(*)$ \\
\hline$*:$ criteria for water; \\
\hline$+:$ maximum level of contamination; \\
\hline \#: level that should never be exceeded \\
\hline
\end{tabular}

Table 1 Limits for heavy metal concentrations for human consumption (Adapted from: (Food Industry, 2007))

\section{Methodology to be developed}

The AMG is located in the center of the State of Jalisco, in the Río Grande de Santiago basin, within the Valleys of Atemajac and the Tonalá Plain. The mountains that surround the area to the Northwest the Sierra de San Esteban, to the Southeast the mountainous sets Cerro Escondido-San Martín and El Tapatío-La Reyna; to the south, the Cerro del CuatroGachupín-Santa María and to the west, the Sierra de la Primavera (Ramírez-Sánchez et al., 2006). For the selection of leaf samples it was necessary to discard the young or recently sown Ficus benjamina trees. For this, samples were taken of trees whose height was between 1.50 and 2 meters, which already had "mature" leaves and there was already a sufficient accumulation of dust in them. Once the tree was selected and with the protective equipment on, the gardener's scissors were taken and 30 mature leaves were collected.
For the extraction of heavy metals, samples of Ficus benjamina leaves were taken to the laboratory, and acid digestion was performed. The samples were previously homogenized. The determination was made in an atomic absorption spectrophotometer model Varian AA $240 \mathrm{FS}$, with a monochromator of CZERNY-TURNER design, panel of 4 lamps and inert and adjustable nebulization chamber. The technique used was flame (flame) and calibration curves were used. All samples were treated in duplicate. The elements analyzed were $\mathrm{Cd}, \mathrm{Co}, \mathrm{Cr}, \mathrm{Cu}, \mathrm{Ni}, \mathrm{Pb}$ and $\mathrm{Zn}$ with detection limits in ppb. The curve starts at zero, which is distilled water, which calibrates the equipment in each element. The ranges represent the concentration that was used in the first and last standard to form the curve.

\section{Results}

The average concentration values for $\mathrm{Cu}, \mathrm{Zn}$, $\mathrm{Co}, \mathrm{Ni}, \mathrm{Cd}, \mathrm{Pb}$ and $\mathrm{Cr}$ from all sites. The most abundant elements were $\mathrm{Cu}, \mathrm{Pb}$ and $\mathrm{Zn}$, (14.58$24.72 \mathrm{mg} / \mathrm{Kg}$ ) and in lower concentrations are $\mathrm{Cd}, \mathrm{Cr}$, Co and $\mathrm{Ni}(3.46-5.93 \mathrm{mg} / \mathrm{Kg}$ ). The average concentration of all heavy metals (except $\mathrm{Zn}$ ) was higher than the value reported in the "reference plant" proposed by Market (1992). The concentration values for $\mathrm{Cd}, \mathrm{Co}, \mathrm{Pb}$ $\mathrm{Ni}, \mathrm{Cr}$ and $\mathrm{Cu}$ were 69, 26, 20, 3.9, 3.6 and 2.47 times higher than the reference values, respectively. High concentrations can be attributed to the progressive accumulation of metals in the leaves over time.

When comparing the concentration of heavy metals in Ficus benjamina sheets with the normal concentration value reported by other authors, contamination (except $\mathrm{Zn}$ ) is also inferred, although more moderately. Highlight the case for $\mathrm{Ni}$ and $\mathrm{Cd}$, since the concentration ranges that exceed the reference are between 12 and 17 times higher than normal values. The average concentrations for heavy metals deposited in Ficus benjamina sheets collected in the AMG and reported in 2013 for $\mathrm{Cu}, \mathrm{Zn}, \mathrm{Pb}$, $\mathrm{Cd}$ and $\mathrm{Ni}$ were 21.83, 19.50, 5.82, 1.60 and 0.97 mg / Kg, respectively (Gutierrez, 2013). The comparison of these data with those obtained in this work indicates that our metal concentration values were similar, except for $\mathrm{Cd}, \mathrm{Pb}$ and $\mathrm{Ni}$, which were 2.1, 3.4 and 6 times higher. In both cases, heavy metal contamination was inferred in the AMG. 
Correlations were made which reflect an anthropic origin of pollutants from common sources (Machado et al., 2008). For example, $\mathrm{Cr}$ and $\mathrm{Cd}$ are mainly related to emissions from motor oils and $\mathrm{Zn}$ and $\mathrm{Cu}$ are associated with industrial activities and the wear and tear of metal parts from automobiles (Akgüç, Özyiğit, \& Yarci, 2008; Machado et al., 2008; TrujilloGonzález \& Torres-Mora, 2015).

\section{Heavy Metal Distribution}

Next, the distribution of $\mathrm{Cd}, \mathrm{Co}, \mathrm{Cr}, \mathrm{Cu}, \mathrm{Ni}, \mathrm{Pb}$ and $\mathrm{Zn}$ is schematized for each element analyzed by the AA technique. They were added economic activities (DENUE) (INEGI, 2018) that take place in the city and their location in the AMG.

\section{Cadmium $(\mathrm{Cd})$}

This element is associated with the manufacture of accumulators, fertilizer manufacturing, casting of parts and recycling sites. The minimum concentration of $\mathrm{Cd}$ observed was $0.18 \mathrm{ppm}$ and the maximum was $9.20 \mathrm{ppm}$. The area where the highest concentration was observed was at the height of the Revolution division, on Lázaro Cárdenas Avenue and along this road. Industrial activities related to recycling, fertilizer manufacturing, casting of parts and manufacturing of accumulators predominate. Other points of interest are at the height of the Green Cross Leonardo Oliva on the Cruz del Sur Avenue, the zone of the Guadalajara International Airport "Miguel Hidalgo y Costilla" and at the height of the Fractionation Forests Vallarta Residential (Figure 1).
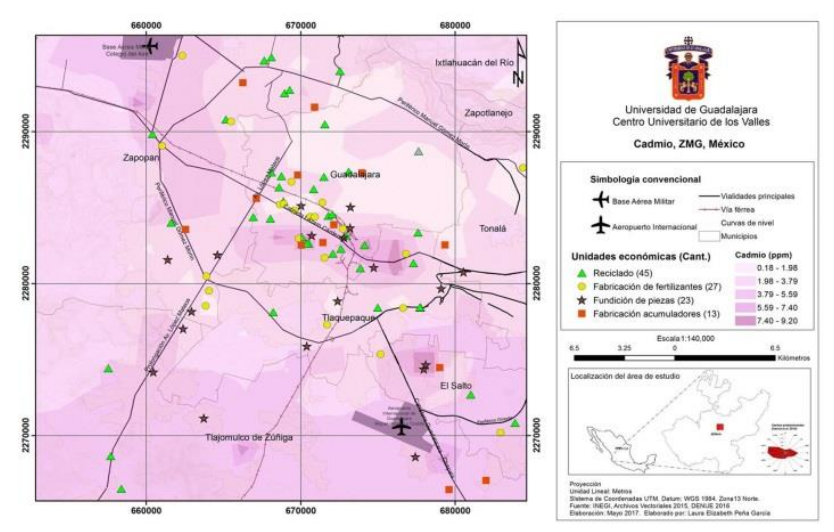

Figure 1 Cadmium distribution map

\section{Cobalt (Co)}

This element is associated with the manufacture of glass and aircraft by-products (engine repair). The minimum concentration of Co was $1.0 \mathrm{ppm}$ and the maximum was $8.0 \mathrm{ppm}$. In general, the AMG has a homogeneous distribution between 3.98 and $6.10 \mathrm{ppm}$. The South-East area of the city is the one with the highest concentrations of $\mathrm{Co}$, as well as some spots within the city.

In the first case bricks predominate that can be a source of contamination by $\mathrm{Co}$ and in the second case, the transport of pollutants by wind could explain the presence of this metal in the urban area. Similarly, Lázaro Cárdenas Avenue and the northern part of the city presented contamination by Co (Figure 2).

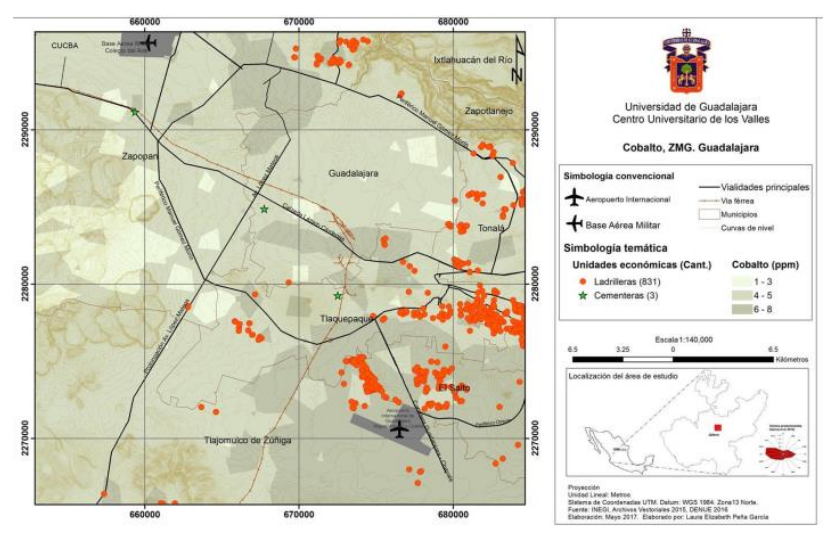

Figure 2 Cobalt distribution map

\section{Chrome (Cr)}

This element is associated with mills, lathes, cast iron parts, iron and steel products and recycling sites. The minimum concentration ranges of $\mathrm{Cr}$ were between 0.01 to $1.43 \mathrm{ppm}$ and maximum between 5.69 and $7.11 \mathrm{ppm}$. The area with the highest concentration is Tonalá, on the New Peripheral East, the eastern part of the city, where you would predominate.

The rest of the AMG has concentrations between $2.85 \mathrm{ppm}$ and $4.27 \mathrm{ppm}$ (Figure 3). In the North zone of the AMG there are recycling activities that can be a source of $\mathrm{Cr}$ and $\mathrm{Cd}$ emissions, confirming a common origin. 

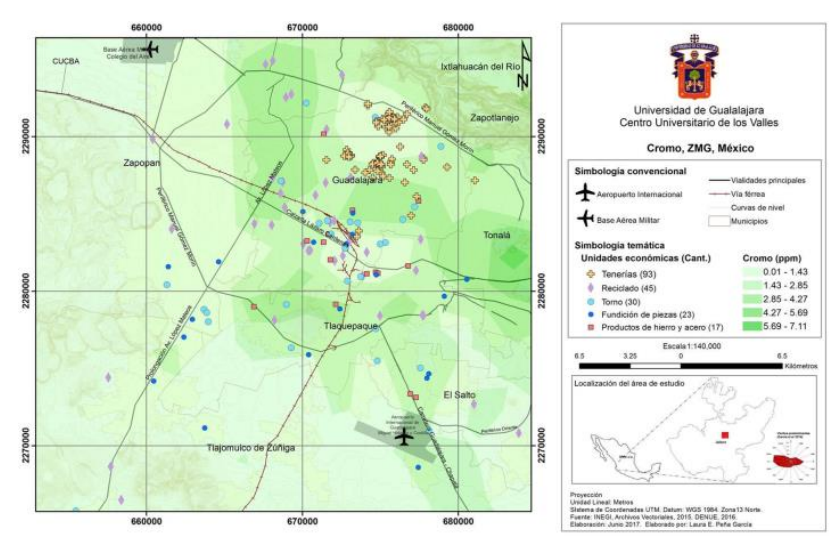

Figure 3 Chrome distribution map

\section{Copper $(\mathrm{Cu})$}

This element is associated with agricultural products, construction of transport vehicles, power lines, trains and cables. The minimum concentration of $\mathrm{Cu}$ in the AMG was between 1.6 and $9.2 \mathrm{ppm}$, the highest was between 32.1 and $39.8 \mathrm{ppm}$. The areas where $\mathrm{Cu}$ is less present in the Zapopan (NW) area, the Camichines area and the Tlajomulco de Zúñiga (Southwest) area of the city (Figure 4). High concentration areas include Guadalajara, Tonalá, Tlaquepaque and El Salto. Among the possible sources of copper predominate activities inherent to the manufacture and lamination of this metal.
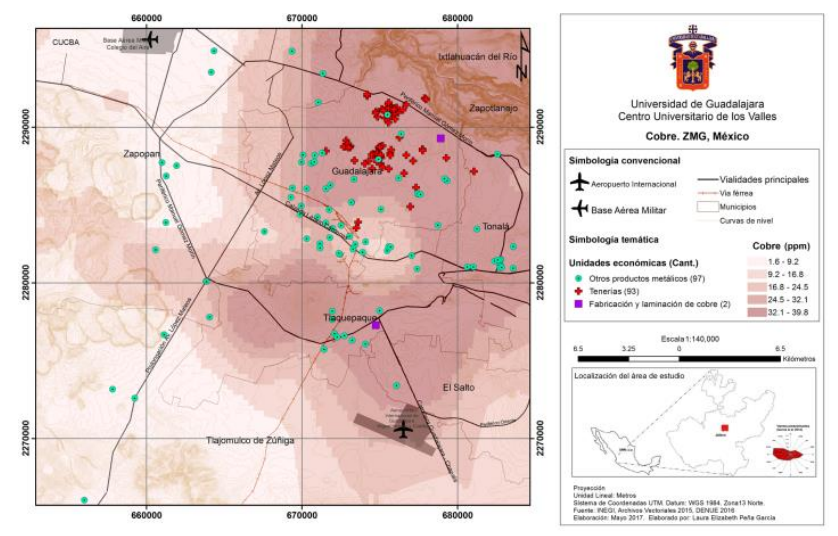

Figure 4 Copper distribution map

\section{Nickel (Ni)}

This element is used in chrome plating machines, for the production of bearings, casting of parts, iron and steel products, generation, transmission and distribution of electrical energy. The minimum value observed was between 0.9 and $4.2 \mathrm{ppm}$ and the maximum between 14.1 and $17.4 \mathrm{ppm}$.
The latter was located in the Spring Forest, agricultural area. It is likely that the use of agrochemicals or $\mathrm{Ni}$ bound to iron ores is the origin of this contamination, since no industrial activities were registered in the area. The minimum values were observed from Lázaro Cárdenas Avenue towards the NE of the city, as well as isolated points within the AMG (Figure $5)$.
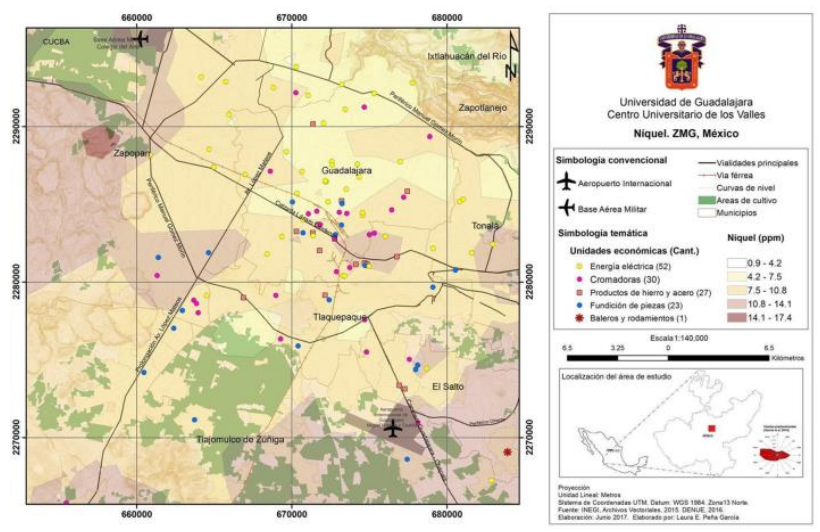

Figure 5 Nickel distribution map

Lead $(\mathrm{Pb})$

For the elaboration of the map the data of the DENUE of:

- $\quad$ Casting of parts,

- Iron and steel products,

- Paint factories,

- Accumulator factories,

- Cement plants,

- $\quad$ Stained glass and leaded and

- Recyclers.

The minimum lead values were between 4.9 and $15.6 \mathrm{ppm}$, the highest concentrations were between 47.6 and $58.2 \mathrm{ppm}$. One of the highest points was located on England Avenue at the height of Regency Park, near North Peripheral. The Air Base area and the Guadalajara International Airport, in addition to certain points on Lázaro Cárdenas Avenue (Figure 6). 


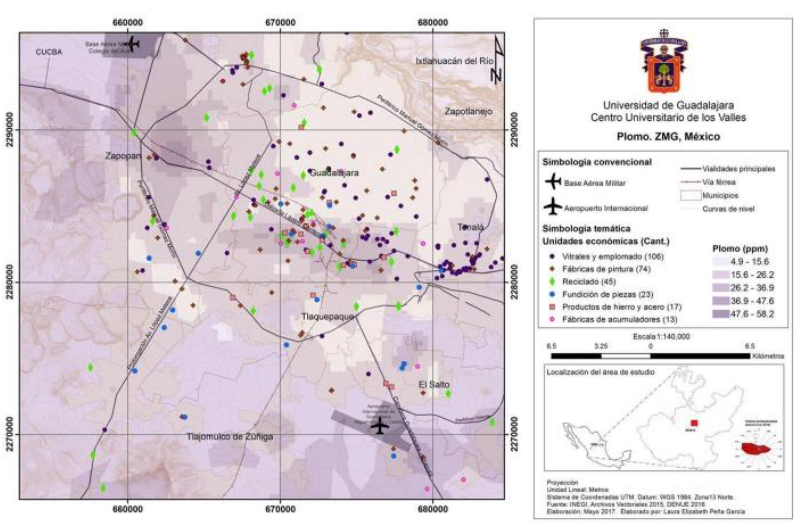

Figure 6 Lead distribution map

Zinc $(\mathrm{Zn})$

For the elaboration of the map the data of the DENUE of:

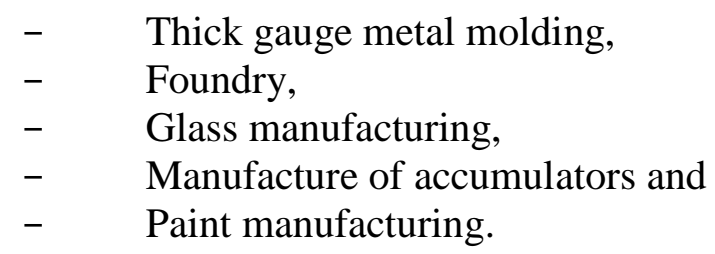

The minimum concentrations of Zinc were between 0.9 and $16.2 \mathrm{ppm}$ and the maximum between 62.2 and $77.5 \mathrm{ppm}$. The points where the highest levels were presented were on the roads of Guadalajara-El Salto, at the height of the IBM company and the other point Guadalajara-Chapala at the height of Revolution Street. In the rest of the city the zone NE, N and NO presented maximum concentrations of 46.9 ppm (Figure 7).
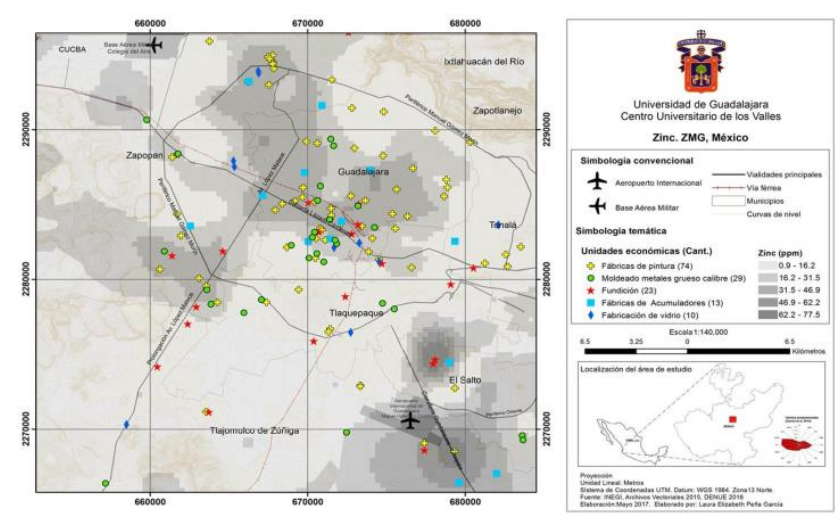

Figure 7 Zinc distribution map

\section{Acknowledgments}

This project received financial support from PROMEP, since, as an academic body, it invited us to participate in a macro project of Networks entitled "Application of numerical modeling of macro and microscale for the diagnosis and prediction of transport and dispersion of pollutants in cities with high pollution rates." The name of the network was: Environmental Impact Studies, and was promoted by the Academic Body UDG-CA-423 Applied Environmental Geosciences of the University of Guadalajara.

To my very dear friends professors MC Elva Guadalupe Robles Jarero, MC Beatriz Rodríguez, MC Gabriela Hernández Pérez, MC Leticia Hernández López, MC Genoveva Pinal Gómez, MC Celia Robles Murguía, MC Martín Pérez Peña, Dr. Roberto Maciel Flores, Dr. Ernesto López Uriarte, MC Armando Toral Flores and Dr. Javier García Velasco. And to the 36 students of the degrees in Biology and Agronomy: Alan Omar Galindo Navarro, Alejandra Monserrat Zepeda Velázquez, Ana Guadalupe García Guadalajara, Ana Karen Sandoval Ontiveros, Ángel Emmanuel Saldívar Sánchez, María Silvia Batres Hernández, Brenely Vianey Cornejo González, Carlos David Mendoza Ocegueda, Cynthia Giselle Navarro Acosta, Daniel Armando Mojica Martínez, Dante Samuel Figueroa Martínez, Erika Andrade González, Fatima Joselyn Muñoz Navarro, Javier Alonso Russell López, Julieta Leticia Mota Sandoval, Karina Guadalupe Lucas Alvarado, Kevin Escobedo Ángeles, Liliana García Hernández, Manuel Del Real Palomares, Margarita Elizabeth García Lerena, María Guadalupe Negrete Reynoso, Mariel Torres Ortiz, Mariela Alejandra Alvarado Enríquez, Miguel Carrasco Ramírez, Mijaíl Farías Flores, Miriam Evelia Pérez Vázquez, Mónica Carolina Báez González, Oscar Alejandro Márquez González, Paulina Marimar Rojas Gallardo, Pedro Gerardo Velázqu ez Orozco, René Adolfo Ramírez Rojas, Rodrigo Gómez Rizo, Rogelio Casillas Ramos, Tonantzin Corral Castelo, Victoria Belén Muñoz Jiménez and Viridiana Cervantes Bueno, who made it possible to lift the samples in a single day. 


\section{Conclusions}

The concentrations of the seven metals analyzed were identified by AA, of which the most abundant were $\mathrm{Cu}$ and $\mathrm{Pb}$. Heavy metal maps allowed us to know that there are some patterns of distribution of pollution. Such was the case of the $\mathrm{Cd}, \mathrm{Pb}$ and $\mathrm{Zn}$ that are distributed very homogeneously on the Lázaro Cárdenas avenue until reaching the supply market area. The above correlates with the heavy metal distribution map obtained by AA, urban dust and with the magnetic characterization maps. The concentration values of $\mathrm{Cd}, \mathrm{Co}, \mathrm{Cr}, \mathrm{Cu}, \mathrm{Ni}$ and $\mathrm{Pb}$ deposited in sheets, exceeded the reference values. The high concentration of heavy metals found shows that the quality of the ambient air in the AMG is unhealthy. It follows that there must be a correlation between this aspect and the health of the population.

\section{References}

Akgüç, N., Özyiğit, I. I., \& Yarci, C. (2008). Pyracantha coccinea roem. (rosaceae) as a biomonitor for $\mathrm{cd}, \mathrm{pb}$ and $\mathrm{zn}$ in mugla province (Turkey). Pakistan Journal of Botany, 40(4 SPEC. ISS.), 1767-1776.

ATSDR. (2001). Resumen de Salud Pública Cobalto (Cobalt). División de Toxicología y Ciencias de La Salud, 1-9. Retrieved from https://www.atsdr.cdc.gov/es/phs/es_phs33.htm 1

ATSDR. (2012a). Resumen de Salud Pública Cadmio (Cadmium). División de Toxicología y Ciencias de La Salud, 8. Retrieved from https://www.atsdr.cdc.gov/es/phs/es_phs5.html

ATSDR. (2012b). Resumen de Salud Pública Cromo (Chromium). División de Toxicología y Ciencias de La Salud, 8. Retrieved from https://www.atsdr.cdc.gov/es/phs/es_phs7.html

ATSDR. (2016a). Resumen de Salud Pública: Cinc (Zinc) | PHS | ATSDR. Retrieved April 12, 2017, from https://www.atsdr.cdc.gov/es/phs/es_phs60.htm 1

ATSDR. (2016b). Resumen de Salud Pública: Níquel (Nickel) | PHS | ATSDR. Retrieved April 11, 2017, from https://www.atsdr.cdc.gov/es/phs/es_phs15.htm 1
ATSDR. (2016c). Resumen de Salud Pública: Plomo (Lead)| PHS | ATSDR. Resúmenes de Salud Pública - Plomo (Lead). Retrieved from https://www.atsdr.cdc.gov/es/phs/es_phs13.htm 1

David, A., \& Wagner, G. (1989). Aparato respiratorio. (Organización Internacional del Trabajo, Ed.), Enciclopedia de Salud y Seguridad en el Trabajo (Tercera ed). Madrid: Organización Internacional del Trabajo. Retrieved from http://www.insht.es/InshtWeb/Contenidos/Docu mentacion/TextosOnline/EnciclopediaOIT/sum ario.pdf

Dreisbach. (1984). Manual De Toxicología Clínica (7a. edició). España: Manual Modeno.

Flores, J., Vaca, M., López, R., González, A., Hachec, R., \& Hernández, M. (2013). Evaluación de la movilidad de plomo y zinc en depósitos secos atmósfericos en el norte de la ciudad de México. Journal of Chemical Information and Modeling, 53(9), 1689-1699. https://doi.org/10.1017/CBO9781107415324.00 4

Frejo, M. T., Díaz, M. J., Lobo, M., García, J., \& Capó, M. (2011). Nanotoxicología ambiental: retos actuales. Medicina Balear, 26(2), 36-46. Retrieved from http://www.medicinabalear.org/pdfs/Vol26n2.p df

Gasser, M., Riediker, M., Mueller, L., Perrenoud, A., Blank, F., Gehr, P., \& RothenRutishauser, B. (2009). Toxic effects of brake wear particles on epithelial lung cells in vitro. Particle and Fibre Toxicology, 6, 30. https://doi.org/10.1186/1743-8977-6-30

Glencore. (2019). Asturiana de Zinc. Retrieved April 12, 2017, from http://www.azsa.es/ES/Paginas/default.aspx

Gutiérrez, P. (2013). Acumulación de contaminantes en especies vegetales e la zona metropolitana de Guadalajara. Universidad de Guadalajara. Retrieved from http://repositorio.cucba.udg.mx:8080/xmlui/bits tream/handle/123456789/5561/Gutierrez_Marti nez_Paulina_Beatriz.pdf? sequence $=1 \&$ is Allow $\mathrm{ed}=\mathrm{y}$ 
Gutiérrez, P. (2015). Biomonitoreo de metales pesados en hojas y frutos de guayabo (Psidium guajava L.) y de guamúchil (Pithecellobium dulce (Roxb.) Benth.) en el Área Metropolitana de Guadalajara. Universidad de Guadalajara. Retrieved from http://repositorio.cucba.udg.mx:8080/xmlui/bits tream/handle/123456789/5918/Gutierrez_Marti nez_Paulina_Beatriz.pdf?sequence $=1 \&$ is Allow $\mathrm{ed}=\mathrm{y}$

Ilundain, J. J. (2009). Libro electrónico de Toxicología clínica. (Servicio Navarro de Salud, Ed.) (1st ed.). Navarra: Servicio Navarro de Salud. Retrieved from https://www.navarra.es/appsext/DescargarFiche ro/default.aspx ?codigoAcceso=PortalDeSalud \& fichero=Toxicologia $\% 5 \mathrm{CMetales.pdf}$

Industria Alimenticia. (2007). Metales pesados y la salud. Retrieved from https://www.industriaalimenticia.com/articles/8 5587-metales-pesados-y-la-salud-humana

INEGI. (2018). Directorio Estadístico Nacional de Unidades Económicas. Retrieved from http://www3.inegi.org.mx/sistemas/mapa/denue /default.aspx

International Zinc Association. (2017). ZINC. International Zinc Association | HomeHome ZINC. International Zinc Association. Retrieved April 12, 2017, from http://www.zinc.org/

Juárez, F. J., Rincón Sánchez, A. R., \& Martínez, R. R. (2009). Toxicología ambiental. Aguascalientes, MEXICO: Universidad Autónoma de Aguascalientes. Retrieved from http://ebookcentral.proquest.com/lib/guadalajar asp/detail.action?docID=3221575

Kowdley, K. (2006). Enfermedad de Wilson. In Netter. Gastroenterología (pp. 792-794). National Library of Medicine. https://doi.org/10.1016/B978-84-458-1567$0.50248-4$

Lenntech. (2008). Propiedades químicas y efectos sobre la salud y el medio ambiente. Retrieved April 11, 2017, from http://www.lenntech.es/periodica/elementos/cd. htm
Machado, A., García, N., García, C., Acosta, L., Córdova, A., Linares, M., ... Velásquez, H. (2008). Contaminación por metales ( $\mathrm{Pb}, \mathrm{Zn}, \mathrm{Ni}$ $\mathrm{Y} \mathrm{Cr}$ ) en aire, sedimentos viales y suelo en una zona de alto tráfico vehicular. Rev. Int. Contam. Ambient, 11(4), 171-182. Retrieved from http://www.scielo.org.co/pdf/luaz/n41/n41a16.p df

Martinez, E. E. (2009). Propiedades magnéticas y sus relaciones con metales pesados $y$ elementos mayores en suelos superficiales del Valle de México. Universidad Autónoma de México. Retrieved from http://www.ptolomeo.unam.mx:8080/xmlui/bits tream/handle/132.248.52.100/1175/Tesis.pdf?se quence $=1$

Nordberg, G. (1999). Metales: propiedades químicas y toxicidad. In Enciclopedia de salud y seguridad en el trabajo (pp. 63.1-63.75). Retrieved from http://www.insht.es/InshtWeb/Contenidos/Docu mentacion/TextosOnline/EnciclopediaOIT/tom o2/63.pdf

OMS. (2006). Ambientes saludables y prevención de enfermedades, hacia una estimación de la carga de morbilidad atribuible al medio ambiente. Organización Mundial de La Salud, 1, 16. Retrieved from http://www.who.int/quantifying_ehimpacts/pub lications/prevdisexecsumsp.pdf?ua=1

OMS. (2016). Cada año mueren 12,6 millones de personas a causa de la insalubridad del medio ambiente. Organización Mundial de La Salud, 1-16. Retrieved from http://www.who.int/es/news-room/detail/15-032016-an-estimated-12-6-million-deaths-eachyear-are-attributable-to-unhealthyenvironments

Organizacion Mundial de la Salud (OMS). (2018). Intoxicación por plomo y salud. https://doi.org/10.1103/PhysRevB.87.115106

Perez Fadul, L. F., \& Hdrnandez Hernandez, L. (2006). Determinación De Metales Pesados En Particulas Respirables E Identificación De Fuentes De Emision, a Partir De Un Muestreo Atmosferico En La Localidad De Puente Aranda En La Ciudad De Bogotá. Universidad de La Salle. Retrieved from https://ciencia.lasalle.edu.co/cgi/viewcontent.cg $i$ ? article $=1672 \&$ context $=$ ing_ambiental_sanitari a

PEÑA-GARCÍA, Laura, MACIEL-FLORES, Roberto, ROSASELGUERA, José and ROBLES-MURGUÍA, Celia. Heavy metals present in Ficus benjamina leaves in the metropolitan area of Guadalajara, Mexico. ECORFAN Journal-Republic of Guatemala. 2019 
Querol, X. (2008). Calidad del aire, partículas en suspensión y metales. Revista Española de Salud Pública, 82(5), 447-453. https://doi.org/10.1590/S113557272008000500001

Ramírez-Sánchez, H. U., Andrade-García, M. D., González-Castañeda, M. E., \& Celis-De La Rosa, A. D. J. (2006). Contaminantes atmosféricos y su correlación con infecciones agudas de las vías respiratorias en niños de Guadalajara, Jalisco. Salud Publica de Mexico, 48(5), 385-394. https://doi.org/10.1590/S003636342006000500005

Tintinalli, J. E., Stapczynski, J. S., \& Cline, D. M. (2013). Tintinalli: Medicina de Urgencias. México, D.F., MEXICO: McGraw-Hill Interamericana. Retrieved from http://ebookcentral.proquest.com/lib/wdgbiblio mhe/detail.action?docID $=3217953$

Trujillo-González, J. M., \& Torres-Mora, M. A. (2015). Evaluación de metales pesados acumulados en polvo vial en tres sectores de la Ciudad de Villavicencio, Colombia. Luna Azul, (41), 296-308. https://doi.org/10.17151/luaz.2015.41.16

Vargas, F. (2005). La contaminación ambiental como factor determinante de la salud. Revista Española de Salud Pública, 79(2), 117-127. https://doi.org/10.1590/S1135-

57272005000200001

Virtual, S. (2011). Propiedades de los metales. Revista Digital Para Profesionales de La Enseñanza, 16, 1-14. Retrieved from http://www.miliarium.com/Prontuario/Tablas/Q uimica/PropiedadesMetales.asp 